\title{
Contribution of local community integration and personal social network support to mental health
}

\author{
Tom Sørensen ${ }^{1}$, Arne Mastekaasa ${ }^{2}$, Inger Sandanger ${ }^{3,4}$, Robert Kleiner ${ }^{5}$, \\ Torbjørn Moum ${ }^{3}$, Olav Klepp ${ }^{1}$ and Nils Bøe ${ }^{1}$ \\ ${ }^{I}$ Department Group of Psychiatry, University of Oslo \\ ${ }^{2}$ Department of Sociology and Human Geography, University of Oslo \\ ${ }^{3}$ Department of Behavioural Science in Medicine, University of Oslo \\ ${ }^{4}$ National Insurance Administration \\ ${ }^{5}$ Temple University (Sociology), Philadelphia
}

Corespondence: Tom Sørensen, Department Group of Psychiatry, Psychiatric Division, Ullevaal University Hospital, 0407 Oslo, Norway Telephone: +47 22118415 or +4791784860 Telefax: +47 22117848 E-mail: tom.sorensen@psykiatri.uio.no

\begin{abstract}
The survey took place in seven local communities in Lofoten in northern Norway, in the first period of a community development program. There were 984 respondents who provided complete data sets. In the present study A.H. Leighton's concept of socio-cultural disintegration were transformed into items that the respondents should answer, giving a subjective evaluation of the degree of integration in a local community. Hence, the local community evaluation is based on nine dimension of socio-cultural integration, constructed from factor analyses of 49 statements about the local community. The individual experience of social support is measured by four items of «Social Cohesion and Support Index» (SCS), based on Cobb's definition. In the surveyed communities we find substantial overlapping contribution of personal social support and socio-cultural integration, to mental health and well-being. The local community however, also has an independent influence. The community index "Contact \& Communication" seems to be a dimension that in particular picks up community properties of importance for the personal social network, but also "Community Identity" and "Security when Sick or Old" have such properties. Other dimensions with significant separate contributions to mental health, like "Milieu Children \& Youth", or "Leisure Time \& Recreation", may reflect stresses and strains (or lack of such) not directly related to one's personal social network. Regarding social support, two items, "belonging to a group" and "help when sick", seem most related to local community properties. On the other hand the item that focuses on the respondents' most intimate relationship, "having someone warm and regardful", seems unaffected by the community indices. "Appreciated by friends" comes in between, and may reflect a network with friends both within and outside the local community. In addition to the overlapping and separate additive effects one also finds interactive effects of social support with some of the community factors.
\end{abstract}

\section{NORSK SAMMENDRAG}

Undersøkelsen er utført i startfasen av et helsefremmingsprosjekt i syv lokalsamfunn i Lofoten. I analysene inngår 984 respondenter med komplette datasett. På grunnlag av A.H. Leightons beskrivelse av sosiokulturell disintegrasjon ble det laget spørsmål hvor folk tok stilling til 49 beskrivelser av grad av integrasjon i sitt lokalsamfunn. Faktoranalyser avdekket ni dimensjoner av sosiokulturell integrasjon. Den enkeltes opplevelse av sosial støtte ble målt ved en indeks, SCS, som er basert på Cobbs definisjon. Man finner at vurderingene av (a) det personlig sosiale nettverket og (b) ens lokalsamfunn både har en separat og en overlappende forklaring i relasjon til mental helse. Lokalsamfunnsindeksen "Kontakt \& kommunikasjon" synes å være en dimensjon som er særlig viktig for det personlige sosiale nettverk. "Lokalsamfunnsidentitet" og "Trygghet ved sykdom og alderdom" synes også å ha slike egenskaper, mens andre dimensjoner som har betydning for mental helse, for eksempel "Miljø for barn \& ungdom" og "Fritid og rekreasjon" synes å fange opp belastninger (eller fravær av slike) som i liten grad er relatert til det personlige sosiale nettverk. Når det gjelder opplevelse av sosial støtte synes to av spørsmålene å være nært knyttet til opplevelse av lokalsamfunn, nemlig "tilhørighet til en gruppe" og "å få hjelp når man er syk". På den annen side synes spørsmålet som fokuserer på personens nærmeste nettverk; "det å ha noen som er varm og oppmerksom", å være helt uavhengig av hvordan lokalsamfunnet vurderes. I en mellomposisjon finner man spørsmålet "å være satt pris på av venner". Dette kan fange opp et vennenettverk som både befinner seg innenfor og utenfor lokalsamfunnet. I tillegg til den separate og overlappende betydning, finner man også interaksjonseffekter mellom noen av lokalsamfunnsfaktorene og den personlige sosial støtte. 


\section{INTRODUCTION}

The present study has roots in the long Norwegian tradition in psychiatric epidemiology. The pioneer was Ødegaard (1) and his study of Norwegian emigrants to USA. He discussed a central issue in psychiatric epidemiology; does an increased psychiatric morbidity reflect the external situation, exposure, or does it reflect a selection of individuals with a disposition for psychiatric morbidity. Also Dalgard, studying migration and functional psychoses, (2) discussed his findings in stress-selection perspective. Where Ødegaard relied mostly on selection, Dalgard argued for the social context of migrants as the explanation. Already the French philosopher Comte put forward the perspective of societal disorganization causing personal disorganization, in 1883 (3). Societal conditions defined in terms of the significance of a community and its relation to individual mental health was advanced by Durkheim (4). The Chicago School $(5,6)$ made significant investigations with a community ecological approach to social conditions.

The linkage of mental disorder to geographic areas with certain characteristics was developed further by Leighton (7). Communities were ordered along a disintegration-integration dimension (8), and correlated with distribution of psychiatric disorders (9). One community was deliberately transformed from a disintegrated to an integrated one, showing at the same time a decrease in mental problems (10-12). This argued for the validity of a causal relationship. Further studies in North America and in other cultures strengthened such a relationship (13-21). However, reviewing the literature did not give many additional studies that used integration-disintegration to analyze mental health. Some studies used it to discuss their findings (22-31). One reason may be that Leighton and his coworkers relied too heavily on extensive, resource demanding fieldwork by trained anthropologists, and that their data could not be reliably connected to degree of socio-cultural integration.

The distribution of psychiatric disorder according to geographic limited populations has also been a strong tradition in Norway, beginning with Bremer's study in Berlevåg (32). Two studies have used "disintegration" as their main explanatory concept. Dalgard (33) looked at neighborhoods in Oslo, which differed in stability, building structure and socioeconomic status, and Sørensen $(34,35)$ compared semi-rural areas with varying proportion of long distance commuters in the population. The present study was the first in which Leighton's indices were translated into items that the respondents should answer, giving a subjective evaluation of the degree of integration in a local community (36).

Personal and societal disorganization and their interrelationship, have been looked into by analogous concepts, for example sense of community $(37,38)$, empowerment $(39,40)$, sense of coherence $(41)$, and social capital (42). However, most prominent as to mental health research, has been social support (43, 44). Leighton (personal communication 1986) states that socio-cultural disintegration in contemporary terms could be described as a community's incapacity to secure the social support of its members. In our work with local communities the idea of socio-cultural integration has been theoretically and practically productive. It has been a premise for the development of a comprehensive community near model for psychiatric services (45) as well as the guiding theory for health promoting projects (46).

The perspective here will be from the individual; how is a person's mental health related to the experience of a local community and support from his/her important social network(s) wherever they are living. How much do these two sources overlap, what is their separate influence, and are there interactions between personal social support and different dimensions of local community support.

\section{METHODS}

\section{Study population and collection of data}

The survey took place in seven local communities in Lofoten in northern Norway from 1991 to 1992, in the first period of a community development program. Work related to fisheries, is important in all the communities. Six of the communities participated in health promotion projects. The seventh asked for help to set up a community profile of problems and assets. The questionnaires were constructed for selfcompletion. They were delivered to all households where people, 18 years or older, were at home during the few days of the survey. From the total eligible population, 1099 questionnaires were collected; that is $65 \%$ of those distributed. We will use data from the 984 respondents who provided complete data sets.

\section{Description of variables}

The local community evaluation is based on nine dimension of socio-cultural integration, constructed from factor analyses of 49 statements about the local community. Additive indices, not weighted by their factor loading, were constructed: INITIATIVE \& COOPERATION, COMMUNITY IDENTITY, FUTURE ECONOMIC VIABILITY, LEISURE TIME \& RECREATION, MILIEU for CHILDREN \& YOUTH, LEADERSHIP, CONTACT \& COMMUNICATION, SECURITY when SICK or OLD, and COMMUNITY HOMOGENEITY. The indices had good construct and predictive validity (36).

The individual experience of social support is measured by four items of «Social Cohesion and Support Index» (SCS), based on Cobb's definition (43). He describes three classes of information: One item relates to «class $1 »$, «information leading the subject to believe that he is cared and loved» ("to have 
somebody close that are warm, attentive and interested in ones doings"), a second item about «class 2», «information leading the subject to believe that he is esteemed and valued» ("appreciated by friends"), and two items regarding «class 3 » «information leading the subject to believe that he belongs to a network of communication and mutual obligation», one about "group belonging" and a second about "the expectation of help from the network; i.e., help when sick". In addition to its construct validity the index has shown high predictive validity, functioning as a «buffer» variable, interacting with negative life events and childhood adversities with regard to mental health $(47,48)$.

Mental health is measured by two indices. Wellbeing has four items; happy-unhappy, satisfieddissatisfied, life rewarding-disappointing, and the Cantril's ladder (49). The second index includes four key Questions about anxiety and depression from Hopkins Symptom Check-list (50).

\section{Statistical methods}

The main method is linear block-wise regression with our two mental health indices as dependent variables. All variables are standardised.

\section{RESULTS}

All correlations go in the expected direction. Community integration indices are more strongly correlated with well-being than with symptoms.

The direct correlation between community indices and WELL, HSCL4, and SCS are all significant at the .001 level.

In our local communities, "Milieu Children \& Youth", and "Contact \& Communication" have the strongest (significant) separate influence (B) on symptoms (HSCL4). Adding social support, SCS, the B for "Contact \& Communication" is substantially reduced, but the others show no reduction. The B for WELL is overall higher, with "Community Identity" as the highest. If we add SCS, "Community Identity" is reduced, and "Contact \& Communication" and "Security when Sick or Old" is no longer significant.

Table 1. Correlation between Community Integration and mental health (HSCL4, WELL) and social support (SCS).

\begin{tabular}{lccc}
\hline & HSCL4 & WELL & SCS* \\
\hline Init.Co-op & .185 & .279 & -.258 \\
LeisureRec & .146 & .218 & -.154 \\
Leadership & .131 & .242 & -.096 \\
ContactCom & .208 & .255 & -.326 \\
Com.Homoge & .089 & .149 & -.148 \\
Comm.ident & .177 & .320 & -.248 \\
FutureEc.V & .153 & .257 & -.249 \\
Mil.Chi.Yo & .247 & .257 & -.161 \\
Sec.SickOl & .156 & .258 & -.309 \\
\hline
\end{tabular}

${ }^{*}$ High HSCL4 $=$ less symptoms, high WELL $=$ higher wellbeing, high SCS $=$ lower social support
Table 2a. B from block-wise regression. 9 Local community integration indices and social support (SCS). Dependent variable WELL.

\begin{tabular}{lcccccc}
\hline & \multicolumn{2}{c}{ Only Com.int. } & & \multicolumn{2}{c}{ Added SCS } \\
\cline { 2 - 3 } \cline { 5 - 6 } & $\mathrm{B}$ & $95 \%$ conf.int. & & $\mathrm{B}$ & $95 \%$ conf. int. \\
\hline Init.Co-op & .044 & $-.027-.114$ & & .018 & $-.045-.081$ \\
LeisureRec & .089 & $.029-.148$ & & .074 & $.021-.127$ \\
Leadership & .106 & $.005-.133$ & & .083 & $.026-.141$ \\
ContactCom & .028 & $.041-.171$ & & .028 & $-.031-.087$ \\
Cult.Homog & .028 & $-.030-.085$ & & .008 & $-.043-.060$ \\
Comm.Ident & .134 & $.063-.206$ & & .107 & $.043-.171$ \\
FutureEc.V & -.004 & $-.053-.08$ & & .002 & $-.060-.064$ \\
Mil.Chi.Yo & .087 & $-.025-.150$ & & .089 & $.033-.144$ \\
Sec.SickO1 & .075 & $.009-.142$ & & .041 & $-.019-.101$ \\
Soc.Supp & & & & -.331 & $-.386--.276$ \\
\hline
\end{tabular}

Table 2b. B from block-wise regression. 9 Local community integration indices and social support (SCS). Dependent variables HSCL4

\begin{tabular}{lrrrrr}
\hline & \multicolumn{2}{c}{ Only Com.int. } & & \multicolumn{2}{c}{ Added SCS } \\
\cline { 2 - 3 } \cline { 5 - 6 } & \multicolumn{1}{c}{$\mathrm{B}$} & $95 \%$ conf. int. & & $\mathrm{B}$ & $95 \%$ conf. int. \\
\hline Init.Co-op & .027 & $-.052-.107$ & & .011 & $-.068-.090$ \\
LeisureRec & .059 & $-.008-.126$ & & .050 & $-.016-.117$ \\
Leadership & .017 & $-.056-.089$ & & .035 & $-.037-.107$ \\
ContactCom & .120 & $.046-.194$ & & .084 & $.009-.158$ \\
Com.Homog & .018 & $-.047-.083$ & & .007 & $-.057-.072$ \\
Com.Ident & .021 & $-.060-.101$ & & .015 & $-.066-.095$ \\
FutureEc.V & -.004 & $-.083-.074$ & & -.016 & $-.094-.062$ \\
Mil.Chi.Yo & .167 & $.097-.237$ & & .167 & $.097-.237$ \\
Sec.SickO1 & .013 & $-.063-.088$ & & -.017 & $-.093-.058$ \\
Soc.Supp & & & & -.189 & $-.258--.120$ \\
\hline
\end{tabular}

Together community indices have an R-sq. of 0.1980 for well-being and 0.0888 for symptoms. Adding social support, give an R-sq. of .3061 and .1155 respectively. We have done regression analyses where we have social support as the first block (not shown). We can then calculate their separate and overlapping contributions. For symptoms, SCS alone explains $2.67 \%$. The community integration indices explain $5.45 \%$, and their overlapping explanation is $3.43 \%$. For well-being the contributions are $10.81 \%, 9.88 \%$ and $9.82 \%$.

The interaction terms between each of the community integration indexes and social support are added as a third block (not shown). HSCL4 R-sq. is raised from .1155 to .1334 . Interactions between two of the community indices with SCS reach significance, namely, "Security when Sick or Old" $(\mathrm{B}=.076, \mathrm{p}<.041)$ and "Future Economic Viability" $(\mathrm{B}=-.090, \mathrm{p}<.019)$, and the interaction with "Contact \& Communication" is close to significance $(\mathrm{B}=.072, \mathrm{p}<.052)$. With WELL $\mathrm{R}$-sq. increases from .3061 to .3226 . Also here there are two significant interactions, namely with, "Future Economic Viability" $(\mathrm{B}=-.109, \mathrm{p}<.000)$, and "Contact \& Communication" $(\mathrm{B}=.062, \mathrm{p}<.034)$, and two close to significance, "Leisure Time \& Recreation" $(\mathrm{B}=.049$, $\mathrm{p}<.069)$, and "Security when Sick or Old" $(\mathrm{B}=.049$, $\mathrm{p}<.094)$. 
Table 3a. B from block-wise regression. The four items of the social support index, SCS (block 1) and the 9 Local community integration indices (block 2). Dependent variable HSCL4.

\begin{tabular}{lccrrrr}
\hline & \multicolumn{2}{c}{ Only SCS items } & & \multicolumn{2}{c}{ Added Com.int. } \\
\cline { 2 - 3 } \cline { 6 - 7 } & $\mathrm{B}$ & $95 \%$ conf. int. & & $\mathrm{B}$ & $95 \%$ conf. int. \\
\hline Help when sick & .011 & $-.065-.088$ & & -.019 & $-.097-.057$ \\
Appreciated by friends & .064 & $-.013-.141$ & & .054 & $-.021-.130$ \\
Somebody regardful & .155 & $.078-.232$ & & .156 & $.081-.231$ \\
Belonging to a group & .178 & $.103-.252$ & & .136 & $.059-.213$ \\
\hline
\end{tabular}

Table 3b. B from block-wise regression. The four items of the social support index, SCS (block 1) and the 9 Local community integration indices (block 2). Dependent variable WELL.

\begin{tabular}{lcrrrrr}
\hline & \multicolumn{2}{c}{ Only SCS items } & & \multicolumn{2}{c}{ Added Com.int. } \\
\cline { 2 - 3 } \cline { 5 - 6 } & $\mathrm{B}$ & $95 \%$ conf. int. & & $\mathrm{B}$ & $95 \%$ conf. int. \\
\hline Help when sick & .059 & $-.003-.122$ & & .011 & $-.050-.071$ \\
Appreciated by friends & .127 & $.065-.190$ & & .123 & $.064-.182$ \\
Somebody regardful & .162 & $.099-.225$ & & .160 & $.101-.219$ \\
Belonging to a group & .217 & $.156-.279$ & & .141 & $.080-.201$ \\
\hline
\end{tabular}

Regarding the relationship between each of the four items of social support and WELL and HSCL4, "belonging to a group", show the highest - and "help when sick" the lowest B. The reduction in B, when adding the community dimensions, is largest in both analyses for "belonging to a group", followed by "help when sick". With respect to the other SCS items there are only minor changes.

\section{Conclusions}

In the surveyed communities we find substantial overlapping contribution of personal social support and socio-cultural integration, to mental health. This is in accordance with our experiences from these communities. Here people have most of their culture, social life and work within the same geographic area. Therefore, there is a considerable overlap between personal social network and local community. The local community however, also has an independent influence. When we add the index of personal social support the betas for some community indexes are reduced, while others are unaffected. Especially "Contact \& Communication" seems to be a dimension that picks up community properties of importance for the personal social network, but also "Community Identity" and "Security when Sick or Old" have such properties. Other dimensions with significant separate contributions to mental health, like "Milieu Children \& Youth", or "Leisure Time \& Recreation", may reflect stresses and strains (or lack of such) not directly related to one's personal social network.

Cobb's definition of social support is multidimensional. Two items, "belonging to a group" and "help when sick", seem to be most related to local community properties in Lofoten. On the other hand the item that focuses on the respondents' most intimate relationship, "having someone warm and regardful", seems unaffected by community indices. "Appreciated by friends" comes in between, and may pick up a mixture of friends both within and outside the local community.

\section{REFERENCES}

1. Ødegaard Ø. Emigration and insanity. Acta Psychiatr Neurol 1932; Suppl. 4.

2. Dalgard OS. Migration and functional psychoses in Oslo. Oslo: Universitetsforlaget, 1968.

3. Bastide R. The sociology of mental disorder. London: Routledge \& Kegan Paul, 1972.

4. Durkheim E. The division of labor in society. New York: Free Press of Glencoe, 1964.

5. Burgess. The urban community. Chicago, 1926.

6. Farris REL, Dunham HW. Mental disorders in urban areas. Chicago, 1934.

7. Leighton AH. My name is Legion. New York: Basic Books, 1959.

8. Hughes CC, Tremblay MA, Rappaport RN, Leighton AH. People of Cove and Woodflot. Communities from the viewpoint of social psychiatry. New York: Basic Books, 1960.

9. Leighton DC, Harding IS, Macklin DB, Mackmillan AM, Leighton AH. The character of danger. Psychiatric symptoms in selected communities. The Stirling County study of psychiatric disorder and socio-cultural environment. Vol. III. New York: Basic Books, 1963.

10. Leighton AH. Poverty and social change. Sci Am 1965; 215: 3-9.

11. Leighton AH. Some notes on preventive psychiatry. Can Psychiatr Assoc J 1967; 12 (Suppl): 43-52.

12. Leighton AH, Murphy J. Primary prevention of psychiatric disorder. Acta Psychiatr Scand 1987; 76 (Suppl. 337): 7-13.

13. Murphy JM. Cross-cultural studies of the prevalence of psychiatric disorders. World Mental Health 1962; 14: 53-65.

14. Leighton AH, Lambo TA, Hughes CC, Leighton DC, Murphy JM, Macklin DB. Psychiatric disorder among the Yoruba. Ithaca, NY: Cornell University Press, 1963. 
15. Leighton AH. A comparative study of psychiatric disorder in Nigeria and rural North America. In: Plog SC, Edgerton RB, eds. Changing perspectives in mental illness. Holt, Rinehart, Winston, 1969.

16. Beiser M, Burr W, Ravel J-L, Collomb H. Illness of the spirit among the Serer of Senegal. J Nerv Ment Dis 1971; 130: 881-886.

17. Beiser M, Ravel J-L, Collomb H, Egelhoft C. Assessing psychiatric disorder among the Serer of Senegal. $J$ Nerv Ment Dis 1972; 154: 141-151.

18. Benfari RC, Beiser M, Leighton AH, Mertens C. Some dimensions of psychoneurotic behaviour in an urban sample. J Nerv Ment Dis 1972; 155: 77-90.

19. Murphy JM. Change and psychiatric disorder among rural Yorubas in Nigeria. Ethos 1973; 1 (2): $239-262$.

20. Cardoza VG, Ackerly WC, Leighton AH. Improving mental health through community action. Community Ment Health $J$ 1975; 11: 215-227.

21. Murphy JM. War stress and civilian Vietnamese. A study of psychological effects. Acta Psychiatr Scand 1977; 56: 92-108.

22. Assael M, German GA. Changing society and mental health in Eastern Africa. Israel Ann Psychiatry Relat Discipl 1970; 8: 52-74.

23. Kern JC. Socio-cultural aspects of poverty. Springboard for action. J Community Psychol 1974; 2: 5-10.

24. Kojak G. The American community in Bangkok, Thailand: A model of social disintegration. Am J Psychiatry 1974; 131: 1229-1233.

25. Lifton RJ, Olson E. The human meaning of total disaster. Psychiatry 1976; 39: 1-18.

26. Matsubara T. Mental hygiene in diminishing population areas. Aust N Z J Psychiatry 1976; 10: 111-113.

27. De-Figueiredo JM. The prevalence of psychosomatic symptoms in a rapidly changing bilingual culture: An exploratory study. Soc Psychiatry 1978; 13: 125-133.

28. De-Figueiredo JM. The law of socio-cultural demoralization. Soc Psychiatry 1983; 18: 73-78.

29. Weingarten M, Orron DE. Schizophrenia in a Yemenite immigrant town in Israel. Int J Soc Psychiatry 1983; 29: 249-254.

30. Moises GF, Richman JA, Flaherty JA, Wintrob RM, et al. Migration and mental health in Peruvian society. Toward a psychosocial model. Soc Psychiatry 1986; 21: 193-199.

31. Phillips MR, Inui TS. The interaction of mental illness, criminal behavior and culture: Native Alaskan mentally ill criminal offenders. Cult Med Psychiatry 1986; 10: 123-149.

32. Bremer J. Social psychiatric investigation of a rural district in northern Norway. Acta Psychiatr Neurol Scand 1951; Suppl. 62.

33. Dalgard OS. Bomiljø og psykisk helse. Oslo: Universitetsforlaget, 1980.

34. Sørensen T. Pendling, lokalmiljø og psykisk helse. En psykiatrisk befolkningsundersøkelse. Stensil. Oslo: Instituttgruppe for psykiatri, Universitetet i Oslo, 1979.

35. Sørensen T. Commuting - community disintegration and psychiatric disorder. In: Sørensen T, Torgersen S, Abrahamsen P, eds. Psychiatric disorder in the social domain. Oslo: Norwegian University Press, 1991.

36. Sørensen T, Kleiner RJ, Bøe N, Moum T, Sandanger I. Sociocultural integration \& disintegration. The localcommunity approach to mental health. North-Coast series in community psychiatry. 01-01. ISBN 82-9219202-8. 1482 Nittedal: North Coast Psychiatry, 2000.

37. Sarason SB. The psychological sense of community. Prospects for a community psychology. San Francisco: Jossey-Bass, 1974.

38. MacMillan DW, Chavis DM. Sense of community. Prospects for a community psychology. J Community Psychol 1986; 14: 6-23.

39. Rappaport J. In praise of a paradox: A social policy of empowerment over prevention. Am J Community Psychol 1981; 9: 1-25.

40. Perkins DD, Zimmerman MA. Empowerment theory, research, and application. Am J Community Psychol 1995; 23: 569-579.

41. Antonovsky A. Unravelling the mystery of health. How people manage stress and stay well. San Francisco: Jossey-Bass Publishers, 1987.

42. Portes A. Social Capital: Its origins and applications in modern sociology. Annu Rev Sociol 1998; 24 : 1-24.

43. Cobb S. Social support as a moderator of life stress. Psychosom Med 1976; 35: 300-314.

44. Sørensen T. The feeling and anticipation of social support; life stress and their impact on mental health. In: Torgersen S, Abrahamsen P, Sørensen T, eds. Psychiatry at the cross-roads between social science and biology. Oslo: Norwegian University Press, 1991.

45. Sørensen T, Sandanger I. The strategic network position: a feasible model for implementing a decentralized psychiatry. Health Promot Int 1989; 4: 297-304.

46. Sørensen T, Bøe N, Ingebrigtsen G, Sandanger I. Individual - local community and mental health. Towards a comprehensive community psychiatric model for prevention of mental problems and promotion of mental health. Nord J Psychiatry 1996; 50 (Suppl 37): 11-19. 
47. Sørensen T. Mental helse i Nordkyst. Bodø: Nordland fylkeskommune, fylkeshelsesjefen, 1987.

48. Sandanger I, Sørensen T, Dalgard OS, Ingebrigtsen G. Barndomsbelatninger, nåtidige belastninger og sosial støtte. Innvirkning på psykisk helse. I: Dalgard OS, Døhlie E, Ystgaard M, red. Sosialt nettverk, helse og samfunn. Oslo: Norwegian University Press, 1995.

49. Sørensen T, Næss S. To measure quality of life. Relevance and use in the psychiatric domain. Nord $J$ Psychiatry 1996; 50 (Suppl 37): 29-39.

50. Sandanger I. Occurrence of psychiatric disorders - an epidemiological study, conceptual, methodological, and empirical issues. Oslo: University of Oslo, ISBN 82-7703-050-9, 1999. 